\title{
Peningkatan Kemampuan Mengenal Huruf Melalui Media Kartu Huruf
}

\section{Putri Hidayah Firdaus}

Pendidikan Islam Anak Usia Dini, Universitas Islam Negeri Sunan Gunung Djati Bandung Jalan Soekarno Hatta Kel. Cimencrang, Gedebage Kota Bandung, Jawa Barat, Indonesia Email: putrihf577@gmail.com

$$
\text { Naskah diterima: } 11 \text { Februari 2019, direvisi: } 6 \text { Maret 2019, diterbitkan: } 30 \text { Maret } 2019
$$

\begin{abstract}
Abstrak
Tujuan observasi ini adalah untuk mengetahui peningkatan kemampuan mengenal huruf pada anak kelompok A Kober Darussalam Ibun Kabupaten Bandung melalui media kartu huruf. Subjek observasi ini adalah anak kelompok A yang berjumlah 22 siswa. Teknik pengumpulan data dilakukan melalui observasi dan wawancara. Hasil observasi menunjukan adanya peningkatan kemampuan mengenal huruf pada siswa Kober Darussalam kelompok A setelah dilakukan pembelajaran dengan menggunakan media kartu huruf, yang awalnya berada pada persentase sebesar 45,44\% menjadi 86,26\%. Dengan demikian penggunaan media kartu huruf dalam pembelajaran mengenal huruf dapat meningkatkan kemampuan mengenal huruf pada anak kelompok A Kober Darussalam Ibun Kabupaten Bandung.
\end{abstract}

Kata kunci: anak usia dini, kemampuan mengenal huruf, media kartu huruf

\begin{abstract}
The purpose of this observation is to find out the increase in the ability to recognize letters in the children of group A Kober Darussalam Ibun Kabupaten Bandung through letter card media. The subjects of this observation were group $A$ children of 22 students. Data collection techniques are carried out through observation, checklist and interview. The results of the observation showed an increase in the ability to recognize letters in Kober Darussalam students in group A after learning using letter card media, which initially was in the percentage of $45.44 \%$ to $86.26 \%$. Thus the use of letter card media in learning to recognize letters can improve the ability to recognize letters in the children of group A Kober Darussalam Ibun Regency of Bandung.
\end{abstract}

Keywords: Ability to Know Letters, Early childhood, Letter Card Media. 


\section{Pendahuluan}

Pendidikan Anak Usia Dini (PAUD) adalah upaya pembinaan yang ditujukan kepada anak sejak lahir sampai usia 6 (enam) tahun yang dilakukan melalui pemberian rancangan pendidikan untuk membantu pertumbuhan dan perkembangan jasmani dan rohani agar anak memiliki kesiapan dalam memasuki pendidikan lebih lanjut (Permendikbud No 137 tahun 2014). Pendidikan anak usia dini merupakan pendidikan formal jenjang pertama yang dilaksanakan pada sistem pendidikan di Indonesia. Pembelajaran yang terjadi di PAUD adalah proses interaksi antar anak didik, antara anak didik dan pendidik dengan melibatkan orang tua serta sumber belajar pada suasana belajar dan bermain di satuan atau program PAUD. Sedangkan aspek pengembangan yang harus dijadikan pembelajaran di PAUD, adalah aspek agama dan moral, kognitif, fisik-motorik, sosial emosional, seni dan bahasa (Permendikbud No 137 tahun 2014)..

Bahasa menjadi salah satu aspek yang diperhatikan dalam proses perkembangan anak. Oleh karena itu, melatih kemampuan anak untuk menggunakan bahasa dengan baik dan benar sejak dini menjadi kewajiban bagi lingkungan di sekitar anak tersebut agar anak mampu mengekspresikan dirinya dengan baik. Pengembangan bahasa anak akan memudahkan anak untuk mengungkapkan pikiran dan dapat berkomunikasi secara efektif. Pada anak usia 4-5 tahun indikator pencapaian perkembangan keaksaraan yang harus dikuasai adalah mengenal simbol-simbol, mengenal suara-suara hewan/benda yang ada di sekitarnya, membuat coretan yang bermakna, meniru (menuliskan dan mengucapkan) huruf A-Z (Permendikbud No 137 tahun 2014).

Kemampuan keaksaraan yang baik erat hubungannya dengan kemampuan membaca dan menulis anak. Leonhardt, menyatakan bahwa "membaca sangat penting bagi anak. Anak-anak yang gemar membaca akan mempunyai kebahasaan yang tinggi. Mereka akan berbicara, menulis dan memahami gagasan-gagasan yang rumit secara lebih baik". Hal ini diperkuat lagi oleh Tom dan Sobol yang menjelaskan bahwa "anak yang sudah memiliki kesiapan membaca di TK akan lebih percaya diri dan penuh kegembiraan". Proses yang dialami dalam membaca adalah berupa penyajian kembali dan penafsiran suatu kegiatan yang dimulai dari mengenali huruf. Anak-anak harus sudah memahami konsep alfabet sebagai bekal kemampuan membaca, menulis dan berbahasanya (Nurbiana, 2012)

Kemampuan anak dalam mengenal huruf, khususnya konsep pengenalan huruf sudah harus dilakukan sejak usia dini dan program pengenalan keaksaraan di lembaga PAUD dapat menjadi kegiatan pembelajaran yang amat membantu perkembangan keaksaraan anak. 
Berdasarkan pengamatan penulis dan hasil wawancara dengan guru kelas di Kelompok A Kober Darussalam Kecamatan Ibun Kabupaten Bandung, terlihat bahwa mayoritas anak belum mampu memahami mengenai konsep huruf. Hal ini terlihat dari kondisi dimana anak tidak mengenal dengan baik huruf latin, anak juga belum mampu menyusun huruf-huruf yang membentuk namanya, anak kurang mampu membedakan mana suara huruf atau suku kata.

Pembelajaran yang dilakukan kepada anak dalam pengenalan huruf, hanya diajarkan melalui majalah. Penggunaan majalah yang terlalu sering tidak tepat dalam program pembelajaran anak. Dari wawancara dengan guru, didapat informasi bahwa guru kurang memberikan pengenalan mengenai konsep huruf karena keterbatasan media pembelajaran yang dimiliki sekolah, sehingga pengenalan huruf tidak dilakukan melalui media penunjang belajar serta bermain bagi anak.

Oleh karena itu penulis tertarik untuk melakukan observasi yang berjudul "Peningkatan Kemampuan Mengenal Huruf Melalui Media Kartu Huruf' dengan tujuan untuk mengetahui peningkatan kemampuan mengenal huruf pada anak kelompok A Kober Darussalam Kecamatan Ibun Kabupaten Bandung. Pembelajaran menggunakan media ini diharapkan akan menjembatani pemahaman huruf yang abstrak dengan konsep berpikir siswa yang konkret.

\section{Metodologi}

Pengamatan ini dilaksanakan pada Kober Darussalam Kecamatan Ibun Kabupaten Bandung. Waktu pengamatan dilaksanakan pada semester II tahun ajaran 2018/2019. Subjek observasi adalah anak usia 4-5 tahun, kelompok A pada Kober Darussalam Ibun, yang berjumlah 22 anak terdiri atas 8 laki-laki dan 14 perempuan. Teknik pengumpulan data yang digunakan yakni Observasi atau pengamatan yang merupakan proses pengambilan data dalam penelitian melalui pengamatan langsung secara terstruktur sesuai indikator yang ada dalam pedoman observasi. Serta dokumentasi ialah pengambilan data video dan gambar saat aktivitas berlangsung (Hamzah, Uno, 2011).

Analisis data merupakan kegiatan mengolah, menganalisa dan menginterpretasikan data untuk menemukan informasi hingga memiliki makna dan arti yang jelas sesuai dengan tujuan penelitian (Sanjaya, Wina, 2011: 106). Analisis data yang digunakan dalam penelitian ini adalah dengan menganalisa data melalui penjelasan hasil penelitian secara deskriptif dengan kata-kata. 
Analisa data dilakukan berdasarkan hasil observasi yang dikonversi kedalam angkaangka dan dipresentasekan sehingga didapat data kuantitatif yang menunjukkan ketuntasan individu, klasikal yang mengarah pada hasil penelitian. Adapun standar penilaian dari pedoman observasi yang digunakan peneliti akan menggunakan standar penilaian sebagai berikut.

Tabel 1. Acuan Penilaian Pedoman Observasi

\begin{tabular}{|c|c|c|}
\hline Skor & Nilai Mutu & Indikator \\
\hline 1 & $\begin{array}{l}\text { Belum } \\
\text { Berkembang (BB) }\end{array}$ & $\begin{array}{l}\text { Jika dalam pencapaian indikator yang } \\
\text { ditetapkan pada pelaksanaannya harus dengan } \\
\text { bimbingan atau dicontohkan guru }\end{array}$ \\
\hline 2 & $\begin{array}{l}\text { Mulai Berkembang } \\
(\mathrm{MB})\end{array}$ & $\begin{array}{l}\text { Jika dalam pencapaian indikator yang } \\
\text { ditetapkan masih harus diingatkan atau dibantu } \\
\text { guru }\end{array}$ \\
\hline 3 & $\begin{array}{l}\text { Berkembang } \\
\text { Sesuai harapan } \\
(\mathrm{BSH})\end{array}$ & $\begin{array}{l}\text { Jika anak dalam pencapaian indikator yang } \\
\text { ditetapkan sudah dapat melakukannya secara } \\
\text { mandiri dan konsisten tanpa harus diingatkan } \\
\text { dan dicontohkan oleh guru }\end{array}$ \\
\hline 4 & $\begin{array}{l}\text { Berkembang } \\
\text { Sangat Baik (BSB) }\end{array}$ & $\begin{array}{l}\text { Jika anak dalam pencapaian indikator yang } \\
\text { ditetapkan sudah dapat melakukannya secara } \\
\text { mandiri dan dapat membantu temannya yang } \\
\text { belum mampu mencapai indikator yang } \\
\text { ditetapkan. }\end{array}$ \\
\hline
\end{tabular}

Sumber: Tim Direktorat Pembinaan PAUD (2015)

Rumus yang digunakan untuk mencari persentase dalam penelitian ini adalah sebagai berikut.

$$
\mathrm{NP}=\frac{\mathrm{R}}{\mathrm{SM}} \mathrm{X} 100 \% \quad \text { (Purwanto, 2006) }
$$

Keterangan:

NP : Nilai persentase yang dicari atau yang diharapkan

R : Skor mentah yang diperoleh anak

SM : Skor maksimum ideal dari tes yang bersangkutan

100 : Bilangan tetap

Setelah diperoleh skor setiap anak dan nilai rata-ratanya secara klasikal, kemudian hasilnya diinterpretasikan pada skala kualifikasi sebagai berikut. 
Tabel 2. Interval dan Kategori Hasil Belajar

\begin{tabular}{ccc}
\hline No. & Interval & Predikat \\
\hline 1 & $80-100$ & Sangat baik \\
2 & $70-79$ & Baik \\
3 & $60-69$ & Cukup \\
4 & $50-59$ & Kurang \\
5 & $0-50$ & Kurang sekali \\
\hline \multicolumn{3}{c}{ Sumber: Syah (2012) }
\end{tabular}

Berikut adalah kisi-kisi pedoman observasi yang digunakan dalam pengamatan ini, dimana selanjutnya akan dijadikan panduan untuk menyusun pedoman observasi untuk mengamati perkembangan kemampuan mengenal huruf anak dalam kegiatan pembelajaran dengankartu huruf.

Tabel 3. Kisi-Kisi Pedoman Observasi

\begin{tabular}{ll}
\hline \multicolumn{1}{c}{ Variabel } & \multicolumn{1}{c}{ Indikator } \\
\hline Kemampuan & Menyebutkan simbol huruf dengan benar \\
Mengenal & Menunjukkan simbol huruf dengan benar \\
Huruf & Menghubungkan gambar dan huruf awal dengan benar \\
& Menuliskan huruf dengan benar \\
\hline
\end{tabular}

\section{Hasil dan Diskusi}

Hasil pengamatan pada saat sebelum diterapkannya pembelajaran mengenal huruf dengan kartu huruf dengan pembelajaran lewat permainan serta nyanyian-nyanyian, terdapat kemampuan mengenal huruf yang kurang baik pada siswa kelompok A Kober Darussalam Ibun. Terlihat dari perolehan hasil rata-ratanya berada pada 45,44\% yang tergolong pada kategori kurang sekali. Pembelajaran yang dilakukan guru dalam mengajar sangat monoton bagi anak.

Pembelajaran melalui penggunaan majalah dengan cara anak mengerjakan sesuai dengan perintah dari lembar kerja majalah yang kemudian anak diajak untuk menyebutkan satu-satu huruf yang terdapat dalam kalimat. Guru tidak terlalu memperhatikan kemampuan anak, karena guru menyebutkan kemudian anak mengikuti apa yang diucapkan oleh gurunya. Dan sebagian anak kurang antusias ketika pembelajarannya seperti demikian. Sehingga perhatian anak teralihkan oleh hal lain disekitarnya. Berdasarkan pengamatan pada kemampuan mengenal huruf anak pada pengetesan pertama didapat hasil penelitian sebagai berikut. 
Tabel 4. Rekapitulasi Pretest

\begin{tabular}{ccc}
\hline Kriteria & Jumlah Anak & Presentase \\
\hline BB & 2 & $9,1 \%$ \\
MB & 10 & $45,46 \%$ \\
BSH & 7 & $31,81 \%$ \\
BSB & 3 & $13,63 \%$ \\
Jumlah & 22 & $100 \%$ \\
\hline
\end{tabular}

Berdasarkan persentase kemampuan mengenal huruf hasil pengamatan pada saat pretest dapat diketahui bahwa tingkat kemampuan mengenal huruf diperoleh sebesar 45,44\% terlihat dari jumlah total 10 orang siswa yang mencapai berkembang sesuai harapan dan berkembang sangat baik.

Setelah diterapkan pembelajaran dengan menggunakan media kartu huruf, melalui nyanyian serta permainan-permainan, terdapat peningkatan pada kemampuan mengenal huruf anak. Perolehan rata-rata pengetesan setelah dilakukan pembelajaran dengan media kartu huruf sebesar 86,26\% yang menunjukan pada kategori sangat baik. Maka dihitung ratarata hasil observasi kemampuan mengenal huruf pada anak dalam tabel berikut:

Tabel 5. Rekapitulasi Posttest

\begin{tabular}{ccc}
\hline Kriteria & Jumlah Anak & Presentase \\
\hline BB & 0 & 0 \\
MB & 3 & $13,64 \%$ \\
BSH & 13 & $59,09 \%$ \\
BSB & 6 & $27,27 \%$ \\
Jumlah & 22 & $100 \%$ \\
\hline
\end{tabular}

Berdasarkan persentase pada tabel 5 maka kemampuan mengenal huruf pada saat posttest dapat dinyatakan mengalami peningkatan menjadi $86,36 \%$ terlihat dari jumlah total 19 orang siswa yang mencapai berkembang sesuai harapan dan berkembang sangat baik.

Tabel 6. Rata-rata Hasil Observasi Kemampuan Mengenal Huruf

\begin{tabular}{ccc}
\hline Subjek & Pretest & Posttest \\
\hline Kelas A anak usia 4-5 tahun & $45,44 \%$ & $86,26 \%$ \\
\hline
\end{tabular}

Berdasarkan tabel 6 tingkat keterlaksanaan kemampuan mengenal huruf pada anak kelompok A Kober Darussalam Ibun terjadi peningkatan dari yang mulanya 45,44\% dengan kategori kurang sekali, setelah dilakukan pembelajaran dengan media kartu huruf menjadi $86,26 \%$ dengan kategori sangat baik. 
Berdasarkan pelaksanaan pembelajaran melalui media kartu huruf diperoleh hasil bahwa kegiatan pembelajaran mengenal huruf berjalan dengan baik dan mampu memberikan peningkatan terhadap kemampuan mengenal huruf anak kelompok A Kober Darussalam Ibun. Proses pembelajaran yang direfleksikan sebagai berikut, diantaranya, (1) Anak-anak telah mampu menunjuk dan mengambil huruf sesuai perintah dengan benar. (2) Anak-anak mampu mengucapkan bunyi huruf dengan tepat dan artikulasi yang jelas. (3) Hasil perhitungan persentase pada posttest adalah $86,36 \%$ menunjukkan tercapainya indikator keberhasilan yang ditetapkan yaitu $75 \%$.

Pembelajaran dengan menggunakan media sangat besar pemanfaatannya dalam pengenalan huruf terhadap anak usia dini. Selain itu juga penggunaan media penunjang lain memberikan hasil yang lebih baik dan proses pembelajaran yang lebih menarik bagi anak. Media alphabet melaui papantulis dan media alphabet berupa gambar memang sangat mendukung pembelajaran pengenalan huruf abjad. Akan tetapi, akan lebih baik juga jika guru mengombinasikan media tersebut dengan media audio visual sebagai contoh video, DVD, dan lain-lain. Jadi guru tidak hanya memberikan teori saja, tetapi juga memberikan pembelajaran berupa praktik pengenalan huruf abjad dengan menggunakan media audio visual (Yosa, 2012:9). Selain itu, dukungan dari keluarga pun sangat menunjang suksesnya pembelajaran anak terhadap perkembangan serta kemampuan dalam pengenalan huruf, Menurut pendapat Djaali Situasi keluarga (ayah, ibu, saudara, adik, kakak, serta famili) sangat berpengaruh terhadap keberhasilan anak dalam keluarga. Pendidikan orang tua, status ekonomi, rumah kediaman, persentase hubungan orang tua, perkataan dan bimbingan orang tua mempengaruhi pencapaian hasil belajar anak. (Tatik, 2012)

\section{Penutup}

Berdasarkan hasil pengamatan kemampuan mengenal huruf anak kelompok A Kober Darussalam Ibun melalui pembelajaran dengan menggunakan media kartu huruf dapat disimpulkan bahwa metode pembelajaran dengan menggunakan kartu huruf dalam mengenal huruf bagi anak kelompok A Kober Darussalam Ibun memberikan pengaruh yang signifikan. Terlihat dari hasil persentase penilaian rata-rata sebelum pembelajaran atau pada saat posttest berada dalam kategori kurang sekali. Kemudian setelah dilakukan pembelajaran kemampuan mengenal huruf anak meningkat berada dalam kategori sangat baik. 
Berdasarkan kesimpulan di atas ada beberapa saran yang ingin peneliti uraikan yaitu: (1) Pelaksanaan pembelajaran anak usia dini harus sesuai dengan ketentuan bahwasanya anak harus belajar sambil bermain, sehingga dalam mengenalkan huruf kepada anak dilakukan melalui permainan-permainan serta nyanyian-nyanyian yang mampu membuat anak lebih antusias. (2) Sekolah harus menyediakan sedikitnya media pembelajaran yang menunjang bagi anak dalam belajar, seperti kartu huruf, alat matematis, serta hal-hal lain yang menarik minat anak untuk belajar. (3) Guru harus lebih kreatif dalam memberikan pengajaran, membawa suasana belajar menjadi menyenangkan dan lebih kondusif lagi, sesuai dengan ketentuan kegiatan belajar mengajak anak usia dini yang telah ditentukan. Implikasi dari kegiatan pembelajaran kartu huruf dapat meningkatkan kemampuan anak mengenal huruf, sehingga kegiatan ini dapat dilakukan di lembaga PAUD lainnya.

\section{Daftar Pustaka}

Lingkup perkembangan bahasa, aspek keaksaraan, Lampiran 1 Peraturan Menteri Pendidikan dan Kebudayaan No.137 tahun 2014 tentang Standar Nasional PAUD

Nurbiana, D. (2012). Metode Pengembangan Bahasa. Jakarta: Universitas Terbuka.

Peraturan Menteri Pendidikan dan Kebudayaan Nomor 137 Tahun 2014 tentang Standar Nasional Pendidikan Anak Usia Dini.

Purwanto, N. (2006). Prinsip-Prinsip dan Teknik Evaluasi Pengajaran. Bandung: Remaja Rosdakarya, h.102

Sanjaya, W. (2011). Penelitian Tindakan Kelas. Jakarta: Kencana Prenada Media Group, h.106

Tatik, A. (2012). Peningkatan Kemampuan Membaca Permulaan Melalui Penggunaan Media Gambar, https://media.neliti.com/media/publications/118389-ID-peningkatankemampuan-membaca-permulaan.pdf (diunduh tanggal 10 Februari 2019).

Tim Direktorat Pembinaan PAUD. (2015) .Penilaian Pembelajaran Pendidikan Anak Usia Dini. Jakarta : Direktorat Pembinaan PAUD Dierjen PAUD dan pendidikan Masyarakat Kementrian Pendidikan dan Kebudayaan, h.5

Uno, H. B., Nina Lamatenggo, Satria M.A Koni. (2011). Menjadi Peneliti PTK Yang Profesional. Jakarta: Bumi Aksara

Yosa. (2012). Analisis Pembelajaran Pengenalan Huruf dengan Menggunakan Media Alfabet pada Anak Usia 5-6 Tahun. Skripsi. Pontianak : Universitas Tanjungpura. 